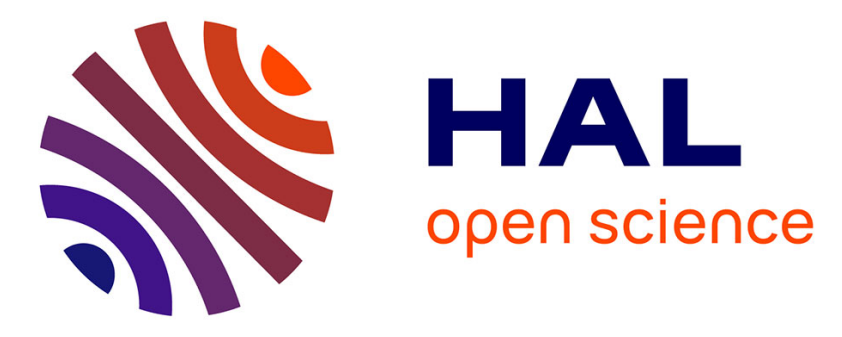

\title{
Optimization of an ethanol/water-based sinapine extraction from mustard bran using Response Surface Methodology
}

Valentin Reungoat, Morvan Gaudin, Amandine Flourat, Emilie Isidore, Louis M.M. Mouterde, Florent Allais, Hélène Ducatel, Irina Ioannou

\section{To cite this version:}

Valentin Reungoat, Morvan Gaudin, Amandine Flourat, Emilie Isidore, Louis M.M. Mouterde, et al.. Optimization of an ethanol/water-based sinapine extraction from mustard bran using Response Surface Methodology. Food and Bioproducts Processing, 2020, 122, pp.322-331. 10.1016/j.fbp.2020.06.001 . hal-02893579

\section{HAL Id: hal-02893579 \\ https://hal.science/hal-02893579}

Submitted on 5 Jan 2022

HAL is a multi-disciplinary open access archive for the deposit and dissemination of scientific research documents, whether they are published or not. The documents may come from teaching and research institutions in France or abroad, or from public or private research centers.
L'archive ouverte pluridisciplinaire HAL, est destinée au dépôt et à la diffusion de documents scientifiques de niveau recherche, publiés ou non, émanant des établissements d'enseignement et de recherche français ou étrangers, des laboratoires publics ou privés. 


\title{
Optimization of an ethanol/water based sinapine extraction from
}

\section{mustard bran using Response Surface Methodology}

Valentin Reungoat $^{\mathrm{a}, \mathrm{b}}$, Morvan Gaudin ${ }^{\mathrm{a}}$, Amandine Flourat ${ }^{\mathrm{a}}$, Emilie Isidore ${ }^{\mathrm{a}}$, Louis Mouterde ${ }^{\mathrm{a}}$, Florent Allais $^{\mathrm{a}}$, Hélène Ducatel ${ }^{\mathrm{b}}$, Irina Ioannou ${ }^{\mathrm{a} *}$

a URD Agro-Biotechnologies Industrielles (ABI), CEBB, AgroParisTech, 51110, Pomacle,

\section{France}

${ }^{\mathrm{b}}$ Extractis, 33 avenue Paul Claudel 80480 Dury, France

* Corresponding author. Email address: irina.ioannou@agroparistech.fr (I. Ioannou)

\begin{abstract}
This study reports an optimization of the extraction of sinapine from industrial mustard bran using an ethanol/water mixture as a green solvent. Response surface methodology was used to determine the optimal operating conditions for the extraction process. The results show that to obtain a maximum yield of sinapine, the extraction process must be carried out at $75^{\circ} \mathrm{C}$ with $70 \%$ ethanol and a ratio of $10 \mathrm{~mL} / \mathrm{g}_{\mathrm{BDM}}$. Under these conditions, the extraction kinetics have shown that equilibrium is reached for a concentration of $8.8 \pm 0.1 \mathrm{mg} / \mathrm{g}_{\mathrm{BDM}}$ in $30 \mathrm{~min}$. The mustard bran is exhausted to $95 \%$ sinapine after two successive extractions. The selectivity of the extraction process for sinapine could be increased by $20 \%$ using an ethanol concentration of $83 \%$, the yield of sinapine is then $8.0 \pm 0.1$ $\mathrm{mg} / \mathrm{g}_{\mathrm{BDM}}$.
\end{abstract}

\section{Keywords}

mustard bran, sinapine extraction, Response Surface Methodology, optimization, kinetics

\section{Nomenclature}

\begin{tabular}{|c|l|}
\hline A & Model constant (dimensionless) \\
\hline BDM & Bran dry matter \\
\hline $\mathrm{C}_{\text {sinapine }}$ & Sinapine concentration in the extract $(\mathrm{mg} / \mathrm{mL})$ \\
\hline EDM & Extract dry matter \\
\hline ESE & Ethyl sinapate equivalent \\
\hline $\mathrm{E}$ or $\mathrm{X}_{2}$ & Concentration of ethanol in the medium solvent $\left(\%_{\mathrm{v} / \mathrm{v}}\right)$ \\
\hline $\mathrm{k}$ & Apparent first-order extraction rate constant $\left(\mathrm{min}^{-1}\right)$ \\
\hline $\mathrm{m}_{\mathrm{BDM}}$ & Mass of dry matter in mustard bran $(\mathrm{g})$ \\
\hline $\mathrm{m}_{\mathrm{EDM}}$ & Mass of dry matter in the extract $(\mathrm{g})$ \\
\hline $\mathrm{m}_{\text {sinapine }}$ & Mass of sinapine in the extract $(\mathrm{g})$ \\
\hline $\mathrm{R}_{\mathrm{i}}$ & Extraction rate for each extraction cycle $(\%)$ \\
\hline $\mathrm{R}^{2}$ & Determination coefficient \\
\hline
\end{tabular}




\begin{tabular}{|c|l|}
\hline $\mathrm{R}^{2}$ adj & Adjusted determination coefficient \\
\hline $\mathrm{S} / \mathrm{M}$ or $\mathrm{X}_{3}$ & Solvent-to-matter ratio $\left(\mathrm{mL} / \mathrm{g}_{\mathrm{BDM}}\right)$ \\
\hline $\mathrm{SAE}$ & Sinapic acid equivalent \\
\hline $\mathrm{V}_{\mathrm{EtOH}}$ & Volume of ethanol added on the mustard bran $(\mathrm{mL})$ \\
\hline $\mathrm{V}_{\mathrm{solvent}}$ & Volume of hydro-ethanolic solvent added on the mustard bran $(\mathrm{mL})$ \\
\hline $\mathrm{T}$ or $\mathrm{X}_{1}$ & Extraction temperature $\left({ }^{\circ} \mathrm{C}\right)$ \\
\hline $\mathrm{t}$ & Time $(\mathrm{min})$ \\
\hline $\mathrm{Y}_{1}$ & Sinapine yield on the mustard bran dry matter $\left(\mathrm{mg} / \mathrm{g}_{\mathrm{BDM}}\right)$ \\
\hline $\mathrm{Y}_{2}$ & Sinapine purity on the extract dry matter $\left(\%_{\mathrm{EDM}}\right)$ \\
\hline $\mathrm{Y}_{\mathrm{t}}$ & Sinapine yield at time $\mathrm{t}\left(\mathrm{mg} / \mathrm{g}_{\mathrm{BDM}}\right)$ \\
\hline $\mathrm{Y}_{\infty}$ & Equilibrium of sinapine yield $\left(\mathrm{mg} / \mathrm{g}_{\mathrm{BDM}}\right)$ \\
\hline
\end{tabular}

\section{Introduction}

Phenolic compounds such as sinapic acid attract more and more attention from researchers due to their many biological activities, particularly free radical scavenging and anti-inflammatory activities, and also their properties such as anti-aging and anti-UV (Nićiforović and Abramovič, 2014). Sinapic acid is particularly interesting as it can be used as a platform molecule for the chemo-enzymatic synthesis of various molecules such as an anti-UV agent (Baker et al., 2016; Dean et al., 2014), a non-endocrine disruptive antiradical additive (Jaufurally et al., 2016) and a bisphenol A substitute for polymer / resin synthesis (Janvier et al., 2017). However, the supply of sustainable sinapic acid is currently based on chemical processes from syringaldehyde (Mouterde and Allais, 2018; Peyrot et al., 2019) that can limit the access to specific markets. One solution to obtain natural molecules would be to use plant biomass, particularly agro-industrial by-products from Brassica species. Indeed, Brassica species such as mustard are rich in sinapine, the choline ester of sinapic acid (Nićiforović and Abramovič, 2014). The mustard species in popular use are Brassica alba, Brassica juncea and Brassica nigra (Thomas et al., 2012). The mustard seeds production peaked at 710 thousand tons in 2018 (FAOSTAT, 2020) and about $60 \%$ of by-products are generated during their processing (Sehwag and Das, 2015). These byproducts, called mustard bran, residue, meal or cake, have a limited use as feed because of some of their anti-nutritive constituents such as sinapine (Matthäus and Angelini, 2005, p. 20; Milkowski and Strack, 2010). The sinapine content is reported at $10 \pm 4 \mathrm{mg} / \mathrm{g}$ of mustard seeds (Bouchereau et al., 1991) with similar content in the by-products (Mayengbam et al., 2014; Wang et al., 1998, p. 98). Thus, the recovery of sinapine from mustard bran would allow accessing a high value-added compound and also sinapic acid after hydrolysis. In addition, the co-products obtained after sinapine extraction could be more valuable for feed.

The extraction of phenolic compounds from mustard by-product are commonly carried out by hydroalcoholic mixtures such as methanol/water or ethanol/water due to their superior efficiency compared to other solvents (Galanakis et al., 2013). Several authors preferred the use of ethanol/water mixtures as a greener and less expensive solvent (Das et al., 2009; Dubie et al., 2013). Moreover, Flourat et al. (2019) and Huang et al, (2012) showed that the ethanol/water mixture is as effective as the methanol/water mixture for phenolic compound extraction from mustard by-product. This extraction depends on the operating conditions of the process. Among the most influent operating conditions reported in the literature, the extraction temperature, the composition of the solvent and the solvent-tomatter ratio were chosen in this study. The optimization of these parameters can be conducted by using Response Surface Methodology. Indeed, this method is an effective mathematical and statistical tool to evaluate the effect of variables and their interactions on the different responses and their optimization (Martínez-Patiño et al., 2019).

This paper is original compared to the works of the literature because our study is based on a precise measurement of the sinapine content by HPLC while the other studies evaluate sinapine through the 
measurement of total phenols by the Folin Ciocalteu assay. This assay is a convenient spectroscopic method, widely used, but not adapted to complex media. Indeed, the TPC may be misestimated due to interferences with other molecules such as amino acids (Stalikas, 2007) or by the choice of the standard (Flourat et al., 2019). As a focus is made on sinapine, a HPLC measurement is preferred to Folin Ciocalteu to assess the extraction efficiency. To our knowledge, no study has carried out an optimization of the extraction process of sinapine from mustard by-products, based on a measurement of the sinapine content with HPLC. In addition, existing studies focused on the optimization of one criteria or several but studied independently. The interaction between the criteria were not investigated. This point is the second originality of this article, the optimization was carried out with DOE and RSM using quadratic models to study the possible interactions between the factors studied. Thus, the objective of our study was to optimize sinapine extraction from mustard bran using a green ethanolic solvent by considering both sinapine yield and the sinapine purity in extract. A first part presents the optimization performed using Response Surface Methodology according to these two criteria. The second part focuses on the development and the modeling of the extraction kinetics of sinapine from mustard bran to reveal the extraction mechanism.

\section{Materials and methods}

\subsection{Materials}

Mustard bran, issue from mustard grown in Canada, was provided by Charbonneaux-Brabant (Reims, France). It is the by-product of the mechanical cold pressing of pickled mustard seeds (Brassica juncea), consisting of seed hulls, residual cotyledons and other minor seed fractions. The material was not defatted, not ground nor dried. The raw mustard bran was stored in a cold room at $4{ }^{\circ} \mathrm{C}$ until used. Pure synthetic sinapine chloride was synthesized in house and used as standard for HPLC analyzes (Peyrot et al., 2020b). The ethanol used for mustard extraction was $>99 \%$ and purchased from ThermoFisher. Formic acid LC-MS and Acetonitrile LC-MS grade for HPLC analysis was purchased from ThermoFisher. MilliQ water was produced by Milli-Q Direct 8 from Merck Millipore (Burlington, USA). Centrifugation was performed in Allegra X15-R from Beckman Coulter.

\subsection{Mustard bran and extract characterizations}

The dry matter (DM) content was determined by drying the mustard bran into an air-flow oven from Binder at $105{ }^{\circ} \mathrm{C}$ overnight. The total phenolic content was determined by the Folin-Ciocalteu's reagent method, adapted from Singleton et al. (1999). Gallic acid was used for calibration. The crude protein content $(\mathrm{N} \times 6.25)$ was determined by the Kjeldahl method, adapted from Bradstreet et al. (1954). A Büchi K-350 distillation unit (Büchi Labortechnik AG, Switzerland) was used. The total sugar content was determined by HPIC (Dionex CarboPac PA1, 4 x $250 \mathrm{~mm}$, ThermoFisher Scientific) after an acidic hydrolysis with $4 \mathrm{~N}$ or $26 \mathrm{~N}$ sulfuric acid for $2.5 \mathrm{~h}$. The cellulose content was determined according to Weende method (Association française de normalisation (AFNOR), 1993). The starch content was determined according to EC 152/2009 (Comission regulation, 2009). The ash content determination was adapted from ISO 749 (International Organization for Standardization (ISO), 1977). The lipid content was determined by hexane extraction according to ISO 734-1 (International Organization for Standardization (ISO), 2006). All results were expressed as percentage of the dry matter.

\subsection{Extraction protocol}

A solid/liquid extraction process using a mixture ethanol/water was carried out on mustard bran in order to separate the sinapine from the solid matter. A fixed volume of $100 \mathrm{~mL}$ of solvent was added 
in a $250-\mathrm{mL}$ tricol flask equipped with a condensing column. The vessel contains a quantity of raw mustard calculated according to the solvent-to-matter ratio. For example, 10,20 and $30 \mathrm{~mL} / \mathrm{g}_{\text {BDM }}$ represented an amount of 18.8, 9.4 and $6.3 \mathrm{~g}$ of raw mustard bran, respectively. Heating was conducted using an IKA RCT heating plate with a heating block with magnetic stirring for $2 \mathrm{~h}$. Solvent temperature was regulated with digital thermometer in contact with solvent and connected to the heating plate. The liquid extract was separated from the bran after centrifugation at $4713 \mathrm{~g}$ for 10 $\min$ at $4{ }^{\circ} \mathrm{C}$. The ethanol/water mixture is considered to be homogeneous, that is to say that the concentration of sinapine in the liquid phase is assumed to be the same everywhere in the mixture.

The experimental conditions varied according to the values of the ethanol concentration in the solvent, the extraction temperature and the solvent-to-matter ratio. The sinapine concentration $\left(\mathrm{C}_{\text {sinapine }}\right)$ was measured by HPLC and expressed in $\mathrm{mg} / \mathrm{mL}$. The dry matter was also determined on the mustard bran and on all the extracts obtained. From these two measurements, two criteria were determined to characterize each extraction:

(i) $\quad \mathrm{Y}_{1}$, the sinapine yield $\left(\mathrm{mg} / \mathrm{g}_{\mathrm{BDM}}\right)$ is expressed according to the dry matter of the mustard bran as shown in Eq.1.

$$
Y_{1}=\frac{C_{\text {sinapine }} * V_{\text {solvent }}}{m_{B D M}} \quad \text { Eq.l }
$$

with $\mathrm{m}_{\mathrm{BDM}}$ the mass of dry matter in mustard bran.

(ii) $\mathrm{Y}_{2}$, the sinapine purity in the extract $\left(\%_{\mathrm{EDW}}\right)$ is expressed according to the dry matter of the extract as shown in Eq.2.

$$
Y_{2}=\frac{m_{\text {sinapine }}}{m_{E D M}} * 100 \quad \text { Eq.2 }
$$

with $m_{E D M}$ the mass of the dry matter in the extract $(\mathrm{g})$ and $m_{\text {sinapine }}$ the mass of sinapine $(\mathrm{g})$ determined from $\mathrm{C}_{\text {sinapine. }}$

Three parameters seem to have an effect on these two criteria: the extraction temperature, the concentration of ethanol into the medium solvent calculated per Eq.3, and the solvent-to-matter ratio calculated according to Eq.4.

$$
\begin{array}{lc}
E=\frac{V_{\text {EtOH }}}{V_{\text {solvent }}} * 100 & \text { Eq.3 } \\
S / M=\frac{V_{\text {solvent }}}{m_{\text {BDM }}} & \text { Eq.4 }
\end{array}
$$

\subsection{Experimental design and statistical analysis}

A CCF design was used to optimize sinapine extraction from mustard bran, with a total of 17 experiments including a triplicate at the central point (Table 1). The independent variables used in this work were the extraction temperature $\mathrm{T}\left(\mathrm{X}_{1}, 45-60-75^{\circ} \mathrm{C}\right)$, the concentration of ethanol into the medium solvent $\mathrm{E}\left(\mathrm{X}_{2}, 45-70-95 \%_{\mathrm{v} / \mathrm{v}}\right)$ and the solvent-to-matter ratio $\mathrm{S} / \mathrm{M}\left(\mathrm{X}_{3}, 10-20-30 \mathrm{~mL} / \mathrm{g}_{\mathrm{BDM}}\right)$. Two responses were optimized: the sinapine yield on the mustard bran dry matter $\left(\mathrm{Y}_{1}, \mathrm{mg} / \mathrm{g}_{\mathrm{BDM}}\right)$ and the sinapine purity on the extract dry matter $\left(\mathrm{Y}_{2}, \%_{\mathrm{EDM}}\right)$. The experimental data were fitted using a second-order polynomial equation Eq.5: 


$$
Y_{q}=\beta_{0}+\sum_{i=1}^{3} \beta_{i} . X_{i}+\sum_{i=1}^{3} \beta_{i i} \cdot X_{i}^{2}+\sum \sum_{i<j=1}^{3} \beta_{i j} . X_{i} . X_{j}+\varepsilon_{\text {residues q }}
$$

where $Y_{q}$ are the different responses ( $\left.q=1-2\right) ; \beta_{0}, \beta_{\mathrm{i}}, \beta_{\mathrm{ij}}, \beta_{\mathrm{ii}}$ are the regression coefficients for the mean, linear, interaction and quadratic terms respectively. $X_{i}$ and $X_{j}$ are the independent variables. $\varepsilon_{\text {residues } q}$ are the differences between the observed and the predicted values.

The experimental domain was not extended above $75{ }^{\circ} \mathrm{C}$ to avoid evaporation phenomena due to the boiling temperature of ethanol.

Table 1 : CCF experimental design

\begin{tabular}{|c|c|c|c|}
\hline \multirow{2}{*}{ Exp. } & $\mathrm{T}\left({ }^{\circ} \mathrm{C}\right)$ & $\mathrm{E}\left(\%_{\mathrm{v} / \mathrm{v}}\right)$ & $\mathrm{S} / \mathrm{M}\left(\mathrm{mL} / \mathrm{g}_{\mathrm{BDM}}\right)$ \\
\hline 1 & $\mathrm{X}_{1}$ & $\mathrm{X}_{2}$ & $\mathrm{X}_{3}$ \\
\hline 2 & 45 & 45 & 10 \\
\hline 3 & 75 & 95 & 10 \\
\hline 4 & 45 & 95 & 10 \\
\hline 5 & 75 & 45 & 10 \\
\hline 6 & 45 & 45 & 30 \\
\hline 7 & 75 & 95 & 30 \\
\hline 8 & 45 & 95 & 30 \\
\hline 9 & 75 & 70 & 30 \\
\hline 10 & 45 & 70 & 20 \\
\hline 11 & 75 & 45 & 20 \\
\hline 12 & 60 & 95 & 20 \\
\hline 13 & 60 & 70 & 10 \\
\hline 14 & 60 & 70 & 30 \\
\hline 15 & 60 & 70 & 20 \\
\hline 16 & 60 & 70 & 20 \\
\hline 17 & 60 & 70 & 20 \\
\hline
\end{tabular}

Commercial software MODDE v.12.0 (Umetrics AB, Sweden) was used to generate the CCF design and analyze experimental data by Response Surface Methodology. An analysis of variance (ANOVA) with 95\% confidence level was then carried out for each response in order to test the model significance and suitability. The effects of each factor were presented by effect plots. The extraction conditions optimized for high sinapine yield on one hand, and the combination of high sinapine yield and purity on the other hand were obtained by the software optimizer tool based on the Nelder-Mead simplex method. These conditions were tested experimentally in duplicate to check the model validity.

\subsection{Extraction kinetics of sinapine from mustard bran}

A kinetic study was conducted in duplicate under the two optimal conditions determined. Samples $(0.8 \mathrm{~mL})$ from the extract were taken at 1, 5, 10, 15, 20, 25, 30, 35, 40 and $60 \mathrm{~min}$ and analyzed by HPLC. At the end of each kinetic, the extract was centrifuged at $4713 \mathrm{~g}$ for $10 \mathrm{~min}$ at 4 ${ }^{\circ} \mathrm{C}$. The sinapine content of the extract was plotted according to the extraction time. The kinetics obtained were modeled according to a derived Fick's law as described by (Chan et al., 2014) Eq.6. The external mass transfer resistance is considered to be negligible.

$$
Y_{t}=Y_{\infty}(1-A \exp (-k t)) \quad \text { Eq.6 }
$$


From the linear plot of $\operatorname{Ln}\left(1-Y_{1} / Y_{\infty}\right)$ against time, the $\mathrm{k}$ values can be determined.

For each optimal condition, the solid residue obtained after the first kinetic was placed in a new 250 $\mathrm{mL}$ tricol vessel for further mustard bran exhaustion cycles. The efficiency of each extraction cycle was assessed with the extraction rates calculated per Eq.7 :

$$
R_{i}=Y_{1} / \sum_{i=1}^{n} Y_{1} i
$$

where $\mathrm{n}$ is the total number of extraction cycle.

\subsection{HPLC quantification of sinapine}

The mustard extract was filtered through a $0.20 \mu \mathrm{m}$, Chromatofil filter, Xtra RC-20/25, with a 1-mL syringe. Sinapine was quantified by reversed-phase UHPLC-DAD (Ultimate 3000; Dionex, ThermoFisher) equipped with a quadratic pump, auto sampler, column furnace and diode array detector. A gradient elution was performed using water (solvent A), acetonitrile (solvent B), and formic acid $0.1 \%$ (solvent C), on a C18 Thermo Scientific ${ }^{\mathrm{TM}}$ Accucore ${ }^{\mathrm{TM}} \mathrm{aQ} ; 100 \times 3 \mathrm{~mm}$ with $2.6 \mu \mathrm{m}$ particle size. Initial solvent was $45 \% \mathrm{~A}, 5 \% \mathrm{~B}$ and $50 \% \mathrm{C}$. Solvent B gradient followed: $5 \%$ (0 min), $10 \%$ (0.990 $\mathrm{min}), 15 \%$ (3.190 $\mathrm{min}), 30 \%$ (7.440 $\mathrm{min}), 5 \%$ (8.510 $\mathrm{min}$ ) while $\mathrm{C}$ remained constant. The column was maintained at $48{ }^{\circ} \mathrm{C}$ and run at a constant flow rate of $0.8 \mathrm{~mL} / \mathrm{min}$. Chromatograms were acquired at $320 \mathrm{~nm}$ and analyzed with Chromeleon software (Version 6.8). Sinapine was identified by comparing its relative retention time with a standard. Synthetic sinapine chloride was used in the preparation of the calibration curve. No significant differences $(p>0.05)$ were found for the HPLC response either when sinapine was dissolved in pure ethanol or ethanol/water solution.

\subsection{Statistics}

In the optimization studies, the uncertainty on the sinapine content was determined with the standard deviation calculated from the 3 repetitions of the central point of the space studied. Concerning the extraction kinetics, the experiments were carried out twice, a mean of the sinapine content was determined associated with its standard deviation.

\section{Results and discussion}

The optimization of the extraction process of sinapine induces the study of different points. In order to predict the major fractions of impurities present in extracts, a characterization of the mustard bran was performed. Then, the optimization of the extraction was carried out according to the Response Surface Methodology. In the last part, kinetics of sinapine extraction were studied and modeled for the optimal conditions.

\subsection{Mustard bran characterization}

The mustard bran used for this study was characterized. The values obtained, shown Table 2, were compared to the literature values of mustard by-products. 
Table 2: Main characteristics of the mustard bran (mass percentage)

\begin{tabular}{|l|c|c|}
\cline { 2 - 3 } \multicolumn{1}{c|}{} & Mustard bran & $\begin{array}{c}\text { Literature values of } \\
\text { mustard by-products }\end{array}$ \\
\hline Dry matter & $53.3 \%$ & $46-49 \%$ or $93-94 \%$ \\
\hline Crude proteins $^{1}$ & $20.6 \%$ & $16-40 \%$ \\
\hline Crude fat $^{1}$ & $19.3 \%$ & $16-22 \%$ or $0.5-1.3 \%$ \\
\hline Cellulose $^{1}$ & $18.7 \%$ & $4-5 \%$ or $12.5 \%$ (crude fiber) \\
\hline Starch $^{1}$ & $4.9 \%$ & $<1 \%$ \\
\hline $\begin{array}{l}\text { Total sugars }^{1} \\
\quad-\quad \text { other sugars }^{2}\end{array}$ & $10.5 \%$ & Not found \\
$\quad$ glucose $^{3}$ & $\sim 8 \%$ & $5-8 \%$ \\
\hline Ash $^{1}$ & $12.5 \%$ & $1 \%$ \\
\hline Polyphenols $^{1}$ & $0.78 \%$ & \\
\hline
\end{tabular}

${ }^{7}$ Values expressed as dry matter basis. ${ }^{2}$ Other sugars than glucose measured with HPIC after a sulfuric acid hydrolysis (4 N and $26 \mathrm{~N}$ ) for $2.5 \mathrm{~h}^{3}$ Estimated glucose other than from cellulose and starch. ${ }^{4}$ Sarwar et al. (1981), Newkirk et al.(1997), Cheva-Isarakul et al. (2003), Thiyam et al. (Thiyam et al., 2006), Devis and Devis (2011), Maiga et al. (2011), Sehwag and Das (2015), Flourat et al. (2019).

Analysis of the composition of mustard bran showed a high-water content with $46.7 \%$. The dry matter of mustard bran is mainly composed of $20.6 \%$ of crude protein, $19.3 \%$ of crude fat, $18.7 \%$ of cellulose, $4.9 \%$ of starch, $8 \%$ of glucose (other than from starch and cellulose), $10.5 \%$ of other sugars than the glucose and $12.5 \%$ of ash. The remaining $5.5 \%$ corresponds to minor compounds such as polyphenols $(0.78 \%)$ or residual acetic acid from the Dijon mustard process. Other minor compounds have been found in the literature such as lignin $(<1-5 \%$, (Maiga et al., 2011; Marles and Gruber, 2004), phytic acid (3\%, (Khattab et al., 2010b)), glucosinolate (< 1\%, (Newkirk et al., 1997)), isothiocyanate (3.5\%, (Sarwar et al., 1981)) and proanthocyanidin (<1\%, (Marles and Gruber, 2004)).

There is a great variability in the literature for the composition of mustard by-products. Indeed, several authors have explained this variability by the use of different pretreatments (Sehwag and Das, 2015) or other parameters such as plant variety or environmental conditions (Bouchereau et al., 1991). Concerning the dry matter and crude fat contents, two values are indicated. Some mustard by-products are dried, the dry matter can therefore reach 93 to $94 \%$ instead of 46 to $49 \%$ for wet mustard byproducts. In addition, mustard by-products can be defatted, leading to a crude fat content of $0.5-1.3$ $\%$.

The mustard bran studied here belongs to the wet and not defatted by-products. Thus, its composition seems consistent with the data in the literature except for the ash content. This one, higher, is due to the production process of the Dijon mustard from which the bran comes.

\subsection{CCF design results}

A CCF design was used to quantify the effects of three factors with three levels on two responses. The inputs of the CCF design are $\mathrm{T}$ the extraction temperature $\left(45,60,75^{\circ} \mathrm{C}\right)$, E the ethanol concentration in the solvent $(45,70,95 \%)$ and $\mathrm{S} / \mathrm{M}$ the solvent-to-matter ratio $\left(10,20,30 \mathrm{~mL} / \mathrm{g}_{\mathrm{BDM}}\right)$ on the sinapine yield $(\mathrm{mg}($ sinapine $) / \mathrm{gBDM})$ and the sinapine purity in the extract $\left(\%_{\mathrm{EDM}}\right)$.

\subsubsection{Model adequacy}

The CCF design is composed of 17 extractions and multiple regressions using polynomial second order were obtained for the responses. The regression coefficients were determined by analysis of variance (ANOVA) for each model. Table 3 summarizes the statistical parameters obtained. 
Table 3: Model equation coefficients and statistical parameters

\begin{tabular}{|c|c|c|c|}
\hline \multirow{2}{*}{$\begin{array}{l}\text { Related } \\
\text { factors }\end{array}$} & \multirow{2}{*}{$\begin{array}{c}\text { Coefficients } \\
\text { scaled and centered }\end{array}$} & \multicolumn{2}{|c|}{ Coefficients values } \\
\hline & & $\begin{array}{c}\text { Sinapine yield } \\
\mathrm{Y}_{1} \\
\end{array}$ & $\begin{array}{c}\text { Sinapine purity } \\
\mathrm{Y}_{2}\end{array}$ \\
\hline constant & $\beta_{0}$ & 8.3143 & 3.4219 \\
\hline $\mathrm{T}$ & $\beta_{1}$ & 0.7100 & 0.1500 \\
\hline $\mathrm{E}$ & $\beta_{2}$ & $-0.0300^{\mathrm{NS}}$ & 0.3800 \\
\hline $\mathrm{S} / \mathrm{M}$ & $\beta_{3}$ & $-0.0500^{\mathrm{NS}}$ & -0.3360 \\
\hline $\mathrm{T} * \mathrm{E}$ & $\beta_{12}$ & - & - \\
\hline $\mathrm{T} * \mathrm{~S} / \mathrm{M}$ & $\beta_{13}$ & 0.3375 & - \\
\hline $\mathrm{E}^{*} \mathrm{~S} / \mathrm{M}$ & $\beta_{23}$ & - & -0.6875 \\
\hline $\mathrm{T} * \mathrm{~T}$ & $\beta_{11}$ & - & - \\
\hline $\mathrm{E}^{*} \mathrm{E}$ & $\beta_{22}$ & -1.6843 & -0.4656 \\
\hline $\mathrm{S} / \mathrm{M} * \mathrm{~S} / \mathrm{M}$ & $\beta_{33}$ & - & -0.3453 \\
\hline & $\mathrm{R}^{2}$ & 0.90 & 0.97 \\
\hline & $\mathrm{R}^{2}$ adj & 0.86 & 0.94 \\
\hline Model & gression ( $p$ value) & 0.00003 & 0.00002 \\
\hline & producibility & 0.98 & 0.99 \\
\hline & dition number & 2.88 & 4.67 \\
\hline
\end{tabular}

NS: Non-significance of the coefficients

Coefficients are considered as significant for a $p<0.05$. The non-significant coefficients were removed to obtain reduced models. The coefficients of determination for the both reduced models are close to 1 , which indicate good model accuracy. The adjusted determination coefficients are also satisfactory, suggesting an acceptable degree of correlation between the experimental and predicted values. The model regressions were evaluated by the $p$ value for each response. As $p<0.05$, the regressions are considered significant at $95 \%$. The condition number assed the good orthogonality of the both models as it does not exceed 10. Each model reproducibility is also excellent with a value close to 1 . All these statistical parameters indicate that the relationships between the variables and the responses are well described by the models.

\subsubsection{Sinapine yield (Y1)}

The sinapine yield is a key parameter for the optimization, in order to find the adequate operating conditions of the extraction process. Variations of this response were found among the 17 experiments of the CCF design. Indeed, the sinapine yield ranges from 5.3 to $8.9 \mathrm{mg} / \mathrm{g}_{\mathrm{BDM}}$.

The most significant term in the model equation for sinapine yield $\left(\mathrm{Y}_{1}\right)$ was the quadratic term of ethanol concentration $\left(E^{*} \mathrm{E}\right)$ which had a negative impact (Table 3). The positive significant terms were the linear term of temperature $(\mathrm{T})$ and the interaction term of temperature with solvent-to-matter ratio $\left(T^{*} \mathrm{~S} / \mathrm{M}\right)$. Their effects on the response are presented Figure 1 with significant effects $(\mathrm{p}<0.05)$ when the confidence interval does not cross the zero line. 


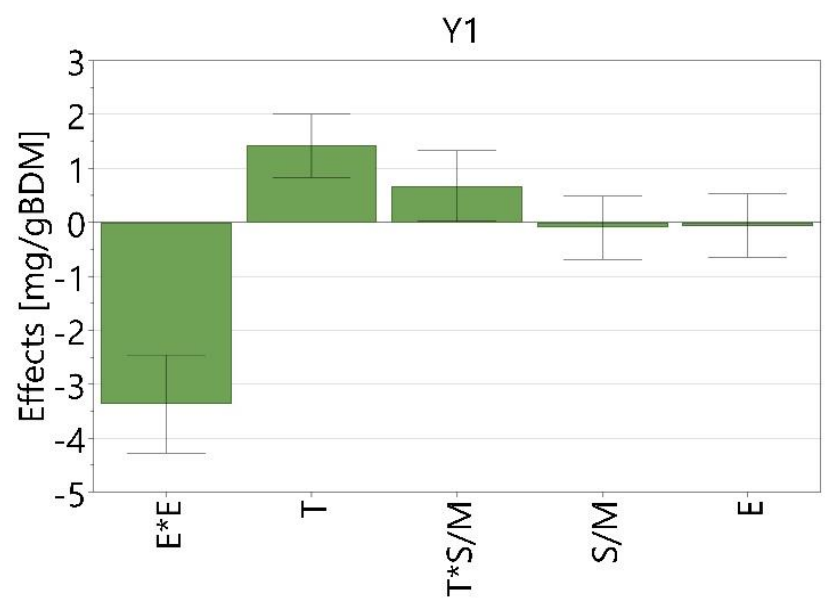

Figure 1 : Effects plot of the variable on sinapine yield.

The model predicting the sinapine yield with unscaled coefficients is shown Eq. 0-8.

$$
\begin{gathered}
\mathbf{Y} 1=-4.8465+0.0023 \mathrm{~T}+\mathbf{0 . 3 7 6 1 E}-\mathbf{0 . 1 4 0 0 S} / \mathrm{M} \\
-\mathbf{0 . 0 0 2 7}(\mathrm{E} * \mathbf{E})+\mathbf{0 . 0 0 2 3}(\mathbf{T} * \mathbf{S} / \mathbf{M})
\end{gathered} \quad \text { Eq. } 0.8
$$

The sinapine yield can be represented with Response Surface as a function of temperature, ethanol concentration at the three levels of solvent-to-matter ratio (Figure 2).
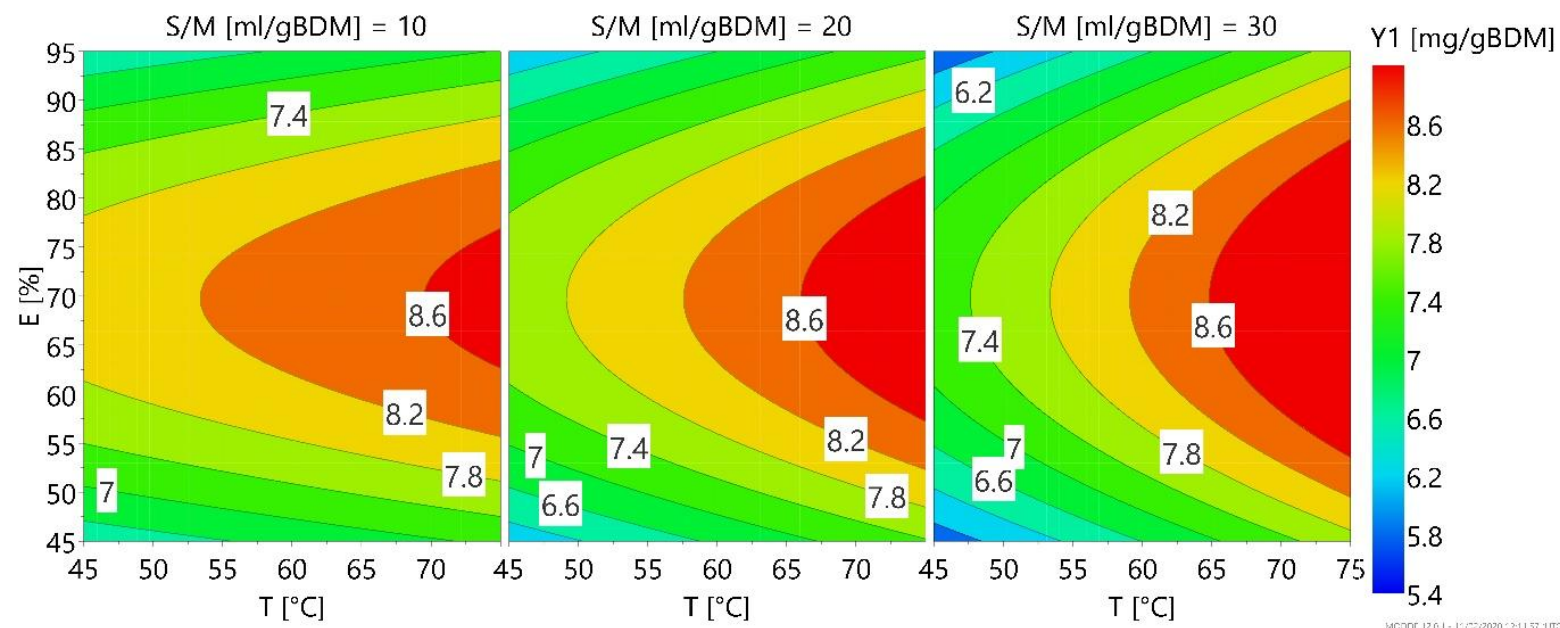

Figure 2 : Response Surface plot of sinapine yield ( $\mathrm{mg} / \mathrm{gBDM})$ after $2 \mathrm{~h}$ extraction

As can be seen on Figure 2, sinapine yield reached a maximum when increasing ethanol concentration in the range of $65-80 \%$ which led to a parabolic shape on the Response Surface. This is due to the high influence of squared ethanol concentration This observation reflects the importance of solvent polarity for compatibility with sinapine. A proportion around $30 \%$ of water is thus required to reach that specific polarity. This can be explained by the positive charge of the choline part of sinapine.

Temperature increase had a positive effect on sinapine yield (Figure 1 and Figure 2). This phenomenon is in accordance with other studies on the optimization of phenolic compounds extraction (Galanakis et al., 2013). Therefore, the higher sinapine yield was reached with the maximum temperature allowed by the system $\left(75^{\circ} \mathrm{C}\right)$. A higher sinapine yield could be expected with higher temperature, thus leading to another technology of extraction such as pressurized solvent which gave interesting results for rapeseed meal ( $\mathrm{Li}$ and Guo, 2016b). 
Figure 1 and Figure 2 show that the solvent-to-matter ratio has little importance on the yield of sinapine. This result means that the limiting phenomenon of the extraction process is not the transfer of the solute from the solid phase to the liquid phase. The solubility of sinapine being high, our conclusion is that the limiting phenomenon of the process of extraction of sinapine from mustard bran is the accessibility of the solvent to reach the target molecule. To reduce costs and energy consumption, the smallest solvent-to-matter ratio $\left(10 \mathrm{~mL} / \mathrm{g}_{\mathrm{BDM}}\right)$ is preferred, which corresponds to a low amount of solvent used during the extraction.

\subsubsection{Sinapine purity (Y2)}

Although our objective was to extract the highest sinapine yield, it seemed also relevant to predict the sinapine purity in the extract because of the purification steps costs. This second model is used to predict the operating conditions allowing the minimization of the impurity content in the extract. The major impurities in the extract include carbohydrates, proteins and minerals.

As seen on Figure 3, the ethanol concentration (E) increase had the most positive impact on sinapine purity (Y2) whereas temperature (T) increase had a low impact. On the contrary, the solvent-to-matter ratio $(\mathrm{S} / \mathrm{M})$ increase and its quadratic term $\left(\mathrm{S} / \mathrm{M}^{*} \mathrm{~S} / \mathrm{M}\right)$ had negative impacts such as the quadratic term of ethanol concentration $\left(\mathrm{E}^{*} \mathrm{E}\right)$ and the interaction term of ethanol concentration with solvent-tomatter ratio $\left(E^{*} S / M\right)$. Those observations are represented with Response Surface on Figure 4.

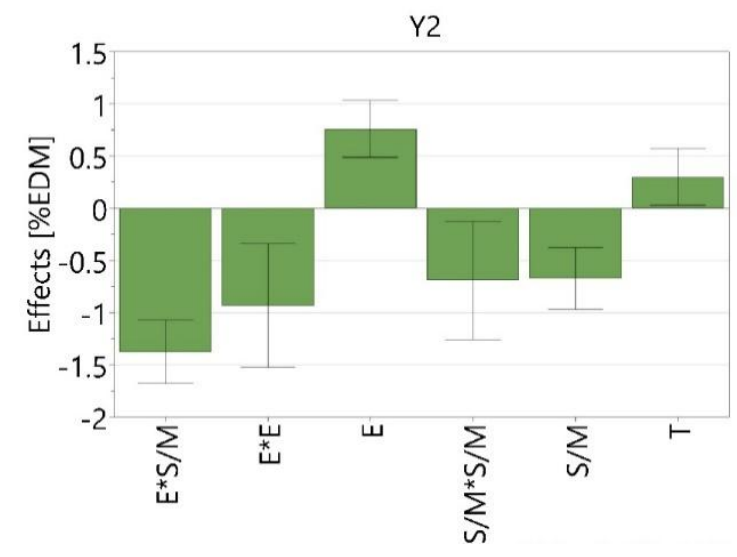

Figure 3 : Effects plot for the variables on sinapine purity (\%EDM).

The experimental sinapine purity ranged between $1.4 \%_{\mathrm{EDM}}$ and $4.4 \%_{\mathrm{EDM}}$. The model application with unscaled coefficients is shown Eq. 0-9.

$\mathrm{Y} 2=-6.4520+0.0100 \mathbf{T}+0.1745 \mathbf{E}+0.2970 \mathbf{S} / \mathbf{M}-0.0007(\mathbf{E} * \mathbf{E})-$ Eq. 0-9 $0.0034(\mathbf{S} / \mathbf{M} * \mathbf{S} / \mathbf{M})-0.0028(\mathbf{E} * \mathbf{S} / \mathbf{M})$ 


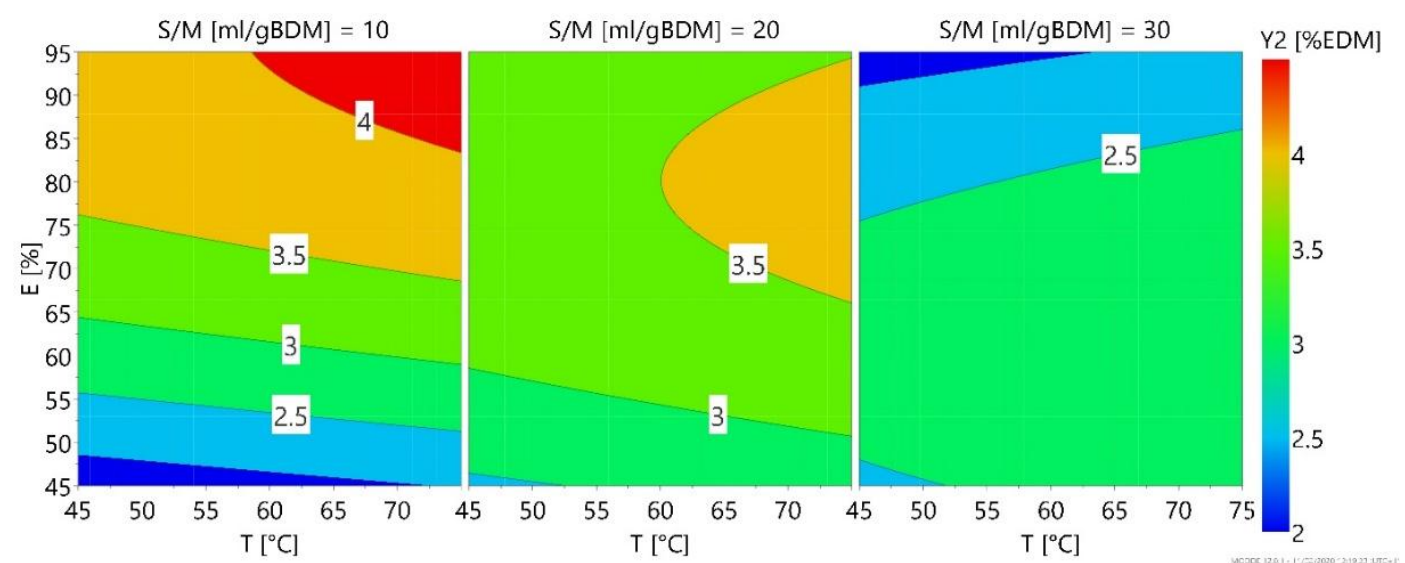

Figure 4 : Response Surface plot of sinapine purity (\%EDM) after $2 \mathrm{~h}$ extraction

The highest purity is obtained with ethanol concentration close to $100 \%$. This may be due to the low solubility of proteins, sugars and minerals in ethanol compared to sinapine. It indicates that an increase of the ethanol concentration increases the process selectivity toward sinapine compared to the other impurities. However, an increase of the solvent-to-matter ratio increases the solubility of those impurities and decreases the sinapine purity in the extract.

The sinapine purity remains low in the extract due to the simultaneous extraction of sugars, proteins and minerals. This phenomenon is commonly observed with a hydro-alcoholic solvent (Galanakis et al., 2013). However, the maximum sinapine purity in the extract reachable with $100 \%$ ethanol concentration was calculated to be $4.2 \%$ EDM whereas the native purity in mustard bran is only up to $0.9 \%_{\mathrm{BDM}}$. Thus, this extraction condition would lead to a 4 -fold more concentrated solution in sinapine.

The increase of sinapine purity in the extract is a very important fact because it will make the purification steps easier and thus allow a reduction in the molecule production costs. However, under this condition, the sinapine yield was calculated to drop to $6.3 \mathrm{mg} / \mathrm{g}_{\text {BDM }}$. Consequently, there is a need to get a compromise between the optimum of the two models.

\subsection{Process optimization and validation of the models}

The sinapine purity obtained being low, it seemed of little interest to optimize this parameter alone. However, considering the optimization of this parameter simultaneously with the optimization of the sinapine yield appeared more relevant. Thus, only two optimal conditions were selected and studied in the next steps using the MODDE software optimization tool.

As $\mathrm{S} / \mathrm{M}$ has little impact on $\mathrm{Y}_{1}$ and negative effect on $\mathrm{Y}_{2}$, the lower solvent-to-matter ratio (10 $\left.\mathrm{mL} / \mathrm{g}_{\mathrm{BDM}}\right)$ was chosen for process optimization in order to reduce the quantity of solvent used.

The first optimal condition concerns the maximization of sinapine yield. Thus, the following operating conditions were $70 \%$ ethanol, $75{ }^{\circ} \mathrm{C}$ and a solvent-to-matter ratio of $10 \mathrm{~mL} / \mathrm{g}_{\text {BDM. }}$. The second optimal condition corresponds to maximizing the sinapine yield and purity of the extract in sinapine. The operating conditions were then $83 \%$ ethanol, $75{ }^{\circ} \mathrm{C}$ and solvent-to-matter ratio of 10 $\mathrm{mL} / \mathrm{g}_{\text {BDM }}$. Under this second condition, the selectivity of the process towards sinapine was increased by $20 \%$ with only $9 \%$ loss of sinapine yield compared to the condition maximizing only the sinapine yield. The contents of molecules present in large quantities were also measured. Thus, the extract was composed of $38 \%$ proteins, $15 \%$ total sugars (HPIC, $4 \mathrm{~N}$ acidic hydrolysis) and $15 \%$ ash. The other compounds of the extract were in minority and have not yet been identified and quantified. It could be organic acids, glucosinolates, phytates or other carbohydrates. 
A comparison between the values predicted by the model and the experimental values was realized for the two optimal conditions with a Student test (Table 4). Experimental values correspond to the values obtained at the equilibrium of sinapine extraction.

Table 4 : Student test to compare predicted and experimental values

Sinapine yield $\left(\mathrm{mg} / \mathrm{g}_{\mathrm{BDM}}\right)$ Condition optimizing sinapine yield $\left(70 \%\right.$ ethanol, $\left.75^{\circ} \mathrm{C}, 10 \mathrm{~mL} / \mathrm{g}_{\mathrm{BDM}}\right)$

\begin{tabular}{|c|c|c|}
\cline { 2 - 3 } \multicolumn{1}{c|}{} & Sinapine yield $\left(\mathrm{mg} / \mathrm{g}_{\text {BDM }}\right)$ & Sinapine purity $\left(\%_{\text {EDM }}\right)$ \\
\hline Condition optimizing sinapine yield $\left(70 \%\right.$ ethanol, $\left.75{ }^{\circ} \mathrm{C}, 10 \mathrm{~mL} / \mathrm{g}_{\text {BDM }}\right)$ \\
\hline Predicted values & $8.7 \pm 0.2 \mathrm{mg} / \mathrm{g}$ & $3.6 \pm 0.7 \%$ \\
\hline Observed values & $8.8 \pm 0.1 \mathrm{mg} / \mathrm{g}$ & $3.5 \pm 0.2 \%$ \\
\hline p-value (Student test) & 0.26 & 0.43 \\
\hline Condition optimizing sinapine yield and purity $\left(83 \%\right.$ ethanol, $\left.75{ }^{\circ} \mathrm{C}, 10 \mathrm{ml} / \mathrm{g}_{\text {BDM }}\right)$ \\
\hline Predicted values & $8.2 \pm 0.2 \mathrm{mg} / \mathrm{g}$ & $4.0 \pm 0.7 \%$ \\
\hline Observed values & $8.0 \pm 0.1 \mathrm{mg} / \mathrm{g}$ & $4.2 \pm 0.1 \%$ \\
\hline p-value (Student test) & 0.11 & 0.30 \\
\hline
\end{tabular}

According to the Student test results, the experimental values reached at the steady state can be considered as equivalent to the values given by the predictive models $(p>0.05)$. Thus, the models found by Response Surface Methodology are validated and can be used for prediction.

Comparing our results with those of other studies in the literature is not easy since only a small number focus on the extraction of phenolic compounds from mustard by-products (Table 5).

Table 5 : Comparison of the sinapine content and extract purity with other similar studies

\begin{tabular}{|c|c|c|c|c|}
\hline $\begin{array}{c}\text { Raw } \\
\text { material }\end{array}$ & $\begin{array}{c}\text { Operating conditions of the } \\
\text { extraction process }\end{array}$ & Sinapine yield & $\begin{array}{c}\text { Sinapine purity } \\
\text { in extract }\end{array}$ & References \\
\hline $\begin{array}{c}\text { Mustard } \\
\text { bran }\end{array}$ & $\begin{array}{c}\text { Ethanol } 70 \% \\
75{ }^{\circ} \mathrm{C}, 30 \mathrm{~min}, 10 \mathrm{~mL} / \mathrm{g}_{\mathrm{BDM}}\end{array}$ & $8.8 \pm 0.1 \mathrm{mg} / \mathrm{g}$ & $3.5 \pm 0.2 \%$ & This study. \\
\hline $\begin{array}{c}\text { Mustard } \\
\text { bran }\end{array}$ & $\begin{array}{c}\text { Ethanol } 83 \% \\
75{ }^{\circ} \mathrm{C}, 40 \mathrm{~min}, 10 \mathrm{~mL} / \mathrm{g}_{\mathrm{BDM}}\end{array}$ & $8.0 \pm 0.1 \mathrm{mg} / \mathrm{g}$ & $4.2 \pm 0.1 \%$ & This study. \\
\hline $\begin{array}{c}\text { Mustard } \\
\text { bran }\end{array}$ & $\begin{array}{c}\text { Ethanol } 65 \% \\
55^{\circ} \mathrm{C}, 240 \mathrm{~min}, 35 \mathrm{~mL} / \mathrm{g}\end{array}$ & $13.71 \mathrm{mg}(\mathrm{ESE}) / \mathrm{g}$ & $\mathrm{Nd}$ & $\begin{array}{c}\text { (Flourat et al., } \\
\text { 2019) }\end{array}$ \\
\hline $\begin{array}{c}\text { Mustard } \\
\text { meal }\end{array}$ & $\begin{array}{c}\text { Ethanol } 70 \% \\
8{ }^{\circ} \mathrm{C}, 3 \times 30 \mathrm{~min}, 20 \mathrm{~mL} / \mathrm{g}\end{array}$ & $8.81 \pm 0.17 \mathrm{mg}(\mathrm{SAE}) / \mathrm{g}$ & $4.0 \%$ & $\begin{array}{c}\text { (Dubie et al., } \\
\text { 2013) }\end{array}$ \\
\hline
\end{tabular}

$\mathrm{Nd}:$ Not determined

Two studies used the same operating conditions as us, but only the total phenolic content was measured. As sinapine is the main phenolic compound in mustard and represents around $90 \%$ of the content (Khattab et al., 2010), we consider as relevant to compare the sinapine content we obtained with the total phenol content they measured. Previous works were realized by Flourat et al. (2019) in our laboratory. They showed that aqueous ethanol was at least as efficient as methanol for phenolic compound extraction. Moreover, they observed that a defatting step prior ethanolic extraction reduces their recovery. The drawback of this study is that the range of the extraction temperature was few extended due to technical limitations. Temperatures between 30 and $55{ }^{\circ} \mathrm{C}$ were used. In addition, the optimization of the extraction process was based only on the total phenolic content measured by the Folin Ciocalteu method. This one is well known to misestimate the amount of phenolic compounds (Stalikas et al., 2007, Flourat et al., 2019). Thus, the study presented in this paper deepens their results by working with a precise measure of the target compound by HPLC and changing the extraction equipment to reach higher temperature (until $75^{\circ} \mathrm{C}$ ).

Dubie et al. (2013) found a sinapic acid equivalent content after extraction of $8.81 \pm 0.17 \mathrm{mg}$ (SAE) / $\mathrm{g}$. This value is consistent with our results $8.8 \pm 0.1 \mathrm{mg} / \mathrm{g}$. The purity of the sinapine in the extract is rarely reported. Only Dubie et al. (2013) reported a purity of sinapic acid equivalent of $4 \%$ in the 
extract whereas we found a purity of $3.5 \pm 0.2 \%$. These results are consistent and confirm the need of a purification step for future applications with sinapine.

\subsection{Extraction kinetics of sinapine under the two optimal conditions}

A kinetic study was carried out on the sinapine extraction for the two optimal conditions chosen. The evolution of the sinapine yield according to the extraction time is presented Figure 5.

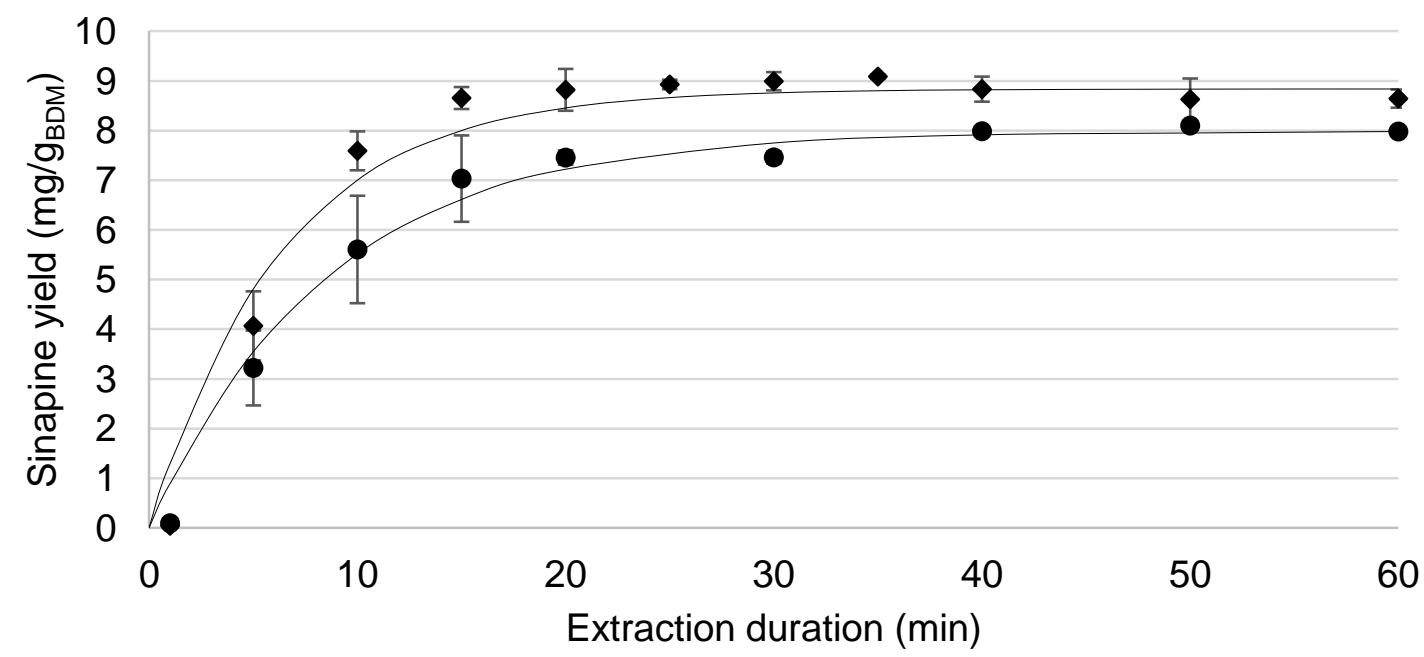

Figure 5 : Extraction kinetics of sinapine from mustard bran under the two conditions. $i(\bullet): 70 \%$ ethanol, $75^{\circ} \mathrm{C}, 10 \mathrm{~mL} / \mathrm{g}_{B D M}$; ii $(\bullet): 83 \%$ ethanol, $75^{\circ} \mathrm{C}, 10 \mathrm{~mL} / \mathrm{g}_{B D M}$

The sinapine extraction kinetics have the same shape for the two optimal conditions. They are characterized by a rapid increase followed by a steady state. This equilibrium state is more rapidly reached with $70 \%$ ethanol than with $83 \%$. Indeed, the sinapine yield is settled after 30 min for the first condition and $40 \mathrm{~min}$ for the second condition. Thus, the others kinetics were stopped to 60 minutes and not pursued until $2 \mathrm{~h}$. The equilibrium sinapine yield is also greater for the first condition than for the second. A value of $8.8 \pm 0.1 \mathrm{mg} / \mathrm{g}_{\text {BDM }}$ was obtained with $70 \%$ ethanol and only $8.0 \pm 0.2 \mathrm{mg} / \mathrm{g}_{\mathrm{BDM}}$ with $83 \%$ of ethanol. These observations are in accordance with the conclusions of the design of experiments. As only the sinapine yield was measured here, it was the condition with $70 \%$ ethanol which made it possible to reach the highest value and in the shortest time. It should be noted that no degradation of sinapine to sinapic acid was observed during the extraction. This means that sinapine was thermostable under acidic $\mathrm{pH}$ due to the acetic acid content in mustard bran.

In order to determine the constant rate of sinapine accumulation in the solvent, the kinetics were modeled using a first-order rate law (Eq.6). Determination coefficients superior to 0.98 were obtained in the both conditions. The sinapine extraction with $70 \%$ ethanol occurs rapidly with a constant rate of $0.157 \mathrm{~min}^{-1}$. It took only 4 and $15 \mathrm{~min}$ to reach $50 \%$ and $90 \%$ of the equilibrium sinapine yield respectively (Figure 5). These results are in accordance with the extraction durations of $30 \mathrm{~min}$ applied by Dubie et al. (2013) under similar conditions. With 83\% ethanol, the extraction kinetic was slower $\left(0.117 \mathrm{~min}^{-1}\right)$. It took $20 \mathrm{~min}$ instead of $15 \mathrm{~min}$ ( $70 \%$ ethanol) to reach $90 \%$ of the equilibrium sinapine yield. To our knowledge, these data have not been previously published. They are essential for the understanding of the phenomena occurring during the extraction process as well as for the scale-up of a production process of biobased sinapic acid. 


\subsection{Exhaustion of mustard bran under the two optimal conditions}

Several successive extractions were realized to exhaust the sinapine from the mustard bran. For each extraction, fresh solvent was added to the bran coming from the previous extraction. The different kinetics are plotted (Figure 6) and modeled (Table 6).

(a)

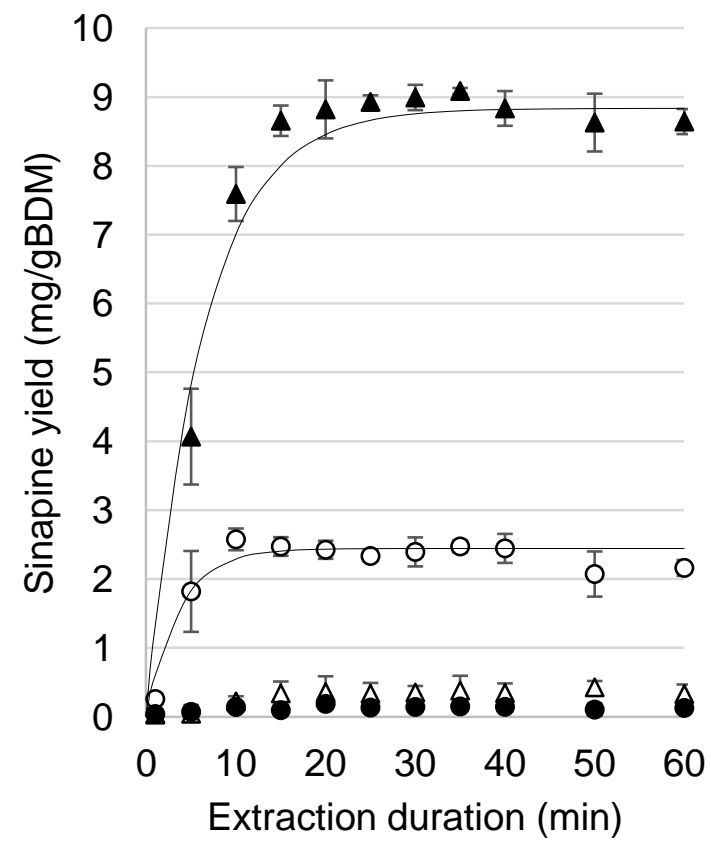

(b)

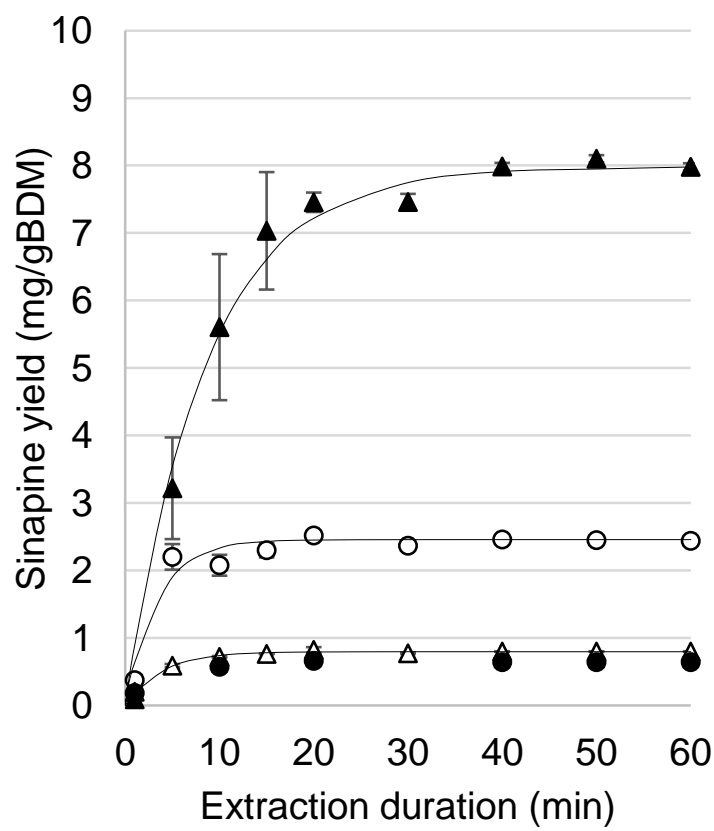

Figure 6 : Exhaustion kinetics under the two optimal conditions (a) $70 \%$ ethanol, $75{ }^{\circ} \mathrm{C}, 10 \mathrm{~mL} / \mathrm{gBDM}$

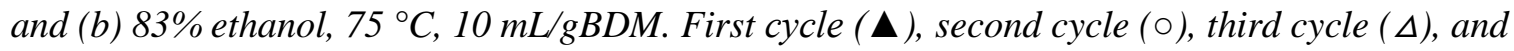
fourth cycle (•)

The sinapine yield reached at the steady state decreased with the number of extractions cycles. The exhaustion occurred more rapidly under the condition with $70 \%$ ethanol than with $83 \%$ ethanol. The total sinapine yield and the extraction rates were calculated for each extraction to determine the required number of extraction cycles in each condition (Table 6).

Table 6: Extraction rate constant $\mathrm{k}\left(\mathrm{min}^{-1}\right)$ and extraction rate per cycle under the two optimum conditions. $\mathrm{Nd}$ : not determined

\begin{tabular}{|c|c|c|c|c|c|c|c|c|}
\cline { 2 - 5 } \multicolumn{1}{c|}{} & \multicolumn{3}{c|}{$\begin{array}{c}\text { Optimizing sinapine yield } \\
\text { (condition with 70\% ethanol) }\end{array}$} & \multicolumn{3}{c|}{$\begin{array}{c}\text { Optimizing sinapine yield and purity } \\
\text { (condition with 83\% ethanol) }\end{array}$} \\
\hline $\begin{array}{c}\text { Cycle } \\
\text { number }\end{array}$ & $\begin{array}{c}\mathrm{k} \\
\left(\mathrm{min}^{-1}\right)\end{array}$ & $\mathrm{R}^{2}$ & $\begin{array}{c}\text { Equilibrium } \\
\text { Sinapine yield } \\
\left(\mathrm{mg} / \mathrm{g}_{\text {BDM }}\right)\end{array}$ & $\begin{array}{c}\text { Extraction } \\
\text { rate per } \\
\text { cycle } \\
(\%)\end{array}$ & $\begin{array}{c}\mathrm{k} \\
\left(\mathrm{min}^{-1}\right)\end{array}$ & $\mathrm{R}^{2}$ & $\begin{array}{c}\text { Equilibrium } \\
\text { Sinapine } \\
\text { yield } \\
\left(\mathrm{mg} / \mathrm{g}_{\text {BDM }}\right)\end{array}$ & $\begin{array}{c}\text { Extraction } \\
\text { rate per } \\
\text { cycle } \\
(\%)\end{array}$ \\
\hline $1^{\text {st }}$ & 0.157 & 0.990 & $8.8 \pm 0.4$ & 75 & 0.117 & 0.991 & $8.0 \pm 0.1$ & 67 \\
\hline $2^{\text {nd }}$ & 0.275 & 0.973 & $2.4 \pm 0.2$ & 20 & 0.297 & 0.936 & $2.5 \pm 0.1$ & 21 \\
\hline $3^{\text {rd }}$ & $\mathrm{Nd}$ & $\mathrm{Nd}$ & $<0.5$ & $\approx 5$ & 0.264 & 0.993 & $0.8 \pm 0.1$ & 7 \\
\hline $4^{\text {th }}$ & $\mathrm{Nd}$ & $\mathrm{Nd}$ & $<0.5$ & $\approx 5$ & $\mathrm{Nd}$ & $\mathrm{Nd}$ & $<0.5$ & $\approx 5$ \\
\hline
\end{tabular}

Under the first condition, the two first extractions made it possible to exhaust the bran in sinapine by 95\%. Indeed, the sinapine yield obtained by the other extraction cycles can be considered as sufficiently low to be neglected. In the second condition, $95 \%$ of the exhaustion was realized within three successive extractions. 
The first-order model shows good fit of the experimental conditions $\left(\mathrm{R}^{2}=0.94-0.99\right)$. Higher constant rates were obtained during the second extraction cycle than the first under both conditions. Indeed, the steady state is reached more rapidly due to the lower quantity to be transferred into the solvent. As expected, an extraction solvent with $70 \%$ ethanol allows faster transfer of the sinapine from the matter to the solvent. However, the transfer of impurities (sugars, proteins, minerals) is also favored by this condition. The use of $83 \%$ ethanol as extraction solvent slows down the mass transfer during the first extraction but also the extraction of impurities. The loss of sinapine induced can be compensated by adding a third extraction cycle in order to achieve the same yield as with $70 \%$ ethanol.

\section{Conclusion}

Optimization of a process for extracting the sinapine from mustard bran was carried out. The highest sinapine yield $\left(8.8 \pm 0.1 \mathrm{mg} / \mathrm{g}_{\text {BDM }}\right)$ was obtained with conventional solvent extraction at $75{ }^{\circ} \mathrm{C}$ and $70 \%(v / v)$ ethanol for $30 \mathrm{~min}$. The limiting phenomenon seems to be the accessibility of the sinapine to the solvent. Increasing the ethanol concentration to $83 \%(\mathrm{v} / \mathrm{v})$ increased the selectivity of sinapine by $20 \%$. Successive extractions effectively released more than $95 \%$ of sinapine from mustard bran in 2 and 3 cycles, respectively, with 70\% (v/v) and 83\% (v/v) ethanol. Future work will focus on optimizing the purification processes of the sinapic extract while conforming to industrial needs in order to develop a viable and environmentally friendly production process of this antioxidant from renewable food products.

\section{Acknowledgements}

This work was supported by Extractis (Amiens, France). We would like to thank the Region Grand Est, the Conseil Départemental de la Marne and the Grand Reims for their financial support, as well as Charbonneaux-Brabant for providing the mustard bran. 


\section{References}

Association française de normalisation (AFNOR), 1993. NF V03-040 - produits agricoles et alimentaires - Détermination de la cellulose brute - Méthode générale

Baker, L.A., Horbury, M.D., Greenough, S.E., Allais, F., Walsh, P.S., Habershon, S., Stavros, V.G., 2016. Ultrafast Photoprotecting Sunscreens in Natural Plants. The Journal of Physical Chemistry Letters 7, 56-61. https://doi.org/10.1021/acs.jpclett.5b02474

Bouchereau, A., Hamelin, J., Lamour, I., Renard, M., Larher, F., 1991. Distribution of sinapine and related compounds in seeds of Brassica and allied genera. Phytochemistry 30, 1873-1881. https://doi.org/10.1016/0031-9422(91)85031-T

Bradstreet, R.B., 1954. Kjeldahl Method for Organic Nitrogen. Analytical Chemistry 26, 185-187. https://doi.org/10.1021/ac60085a028

Chan, C.-H., Yusoff, R., Ngoh, G.-C., 2014. Modeling and kinetics study of conventional and assisted batch solvent extraction. Chemical Engineering Research and Design 92, 1169-1186. https://doi.org/10.1016/j.cherd.2013.10.001

Cheva-Isarakul, B., Tangtaweewipa, S., Piched, S., Yamauchi, K., 2003. Chemical composition and metabolizable energy of mustard meal. Journal of Poultry Science, 40, 221-225. https://doi.org/10.2141/jpsa.40.221

Commission regulation, 2009. EC 152/2009-Polarimetric method, in: Official Journal of the European Union.

Das, R., Bhattacherjee, C., Ghosh, S., 2009. Preparation of Mustard (Brassica juncea L.) Protein Isolate and Recovery of Phenolic Compounds by Ultrafiltration. Industrial \& Engineering Chemistry Research 48, 4939-4947. https://doi.org/10.1021/ie801474q

Dean, J.C., Kusaka, R., Walsh, P.S., Allais, F., Zwier, T.S., 2014. Plant Sunscreens in the UV-B: Ultraviolet Spectroscopy of Jet-Cooled Sinapoyl Malate, Sinapic Acid, and Sinapate Ester Derivatives. Journal of the American Chemical Society 136, 14780-14795. https://doi.org/10.1021/ja5059026

Devis, N., Devis, W., 2011. Nutrient analysis of some poultry feedstuffs locally available in Manipur, India. World journal of Dairy \& Food Sciences 6, 136-139.

Dubie, J., Stancik, A., Morra, M., Nindo, C., 2013. Antioxidant Extraction from Mustard ( Brassica juncea ) Seed Meal Using High-Intensity Ultrasound: Antioxidant extraction from mustard ( Brassica juncea ) seed meal.... Journal of Food Science 78, E542-E548. https://doi.org/10.1111/1750-3841.12085

FAOSTAT, 2020. Production/Yield quantities of Mustard seed [WWW Document]. URL http://www.fao.org/faostat/en/\#data/QV/visualize (accessed 05.06.19).

Flourat, A.L., Willig, G., Teixeira, A.R.S., Allais, F., 2019. Eco-Friendly Extraction of Sinapine From Residues of Mustard Production. Frontiers in Sustainable Food Systems 3. https://doi.org/10.3389/fsufs.2019.00012

Galanakis, C.M., Goulas, V., Tsakona, S., Manganaris, G.A., Gekas, V., 2013. A Knowledge Base for The Recovery of Natural Phenols with Different Solvents. International Journal of Food Properties 16, 382-396. https://doi.org/10.1080/10942912.2010.522750

Huang, S., Huang, M., Feng, B., 2012. Antioxidant Activity of Extracts Produced from Pickled and Dried Mustard (Brassica juncea Coss. Var. foliosa Bailey). International Journal of Food Properties 15, 374-384. https://doi.org/10.1080/10942912.2010.487628

International Organization for Standardization (ISO), 1977. Method 749, oilseed residues Determination of total ash.

International Organization for Standardization (ISO), 2006. Method 734-1, oilseed meals Determination of oil content - Part 1: Extraction method with hexane (or light petroleum).

Janvier, M., Hollande, L., Jaufurally, A.S., Pernes, M., Ménard, R., Grimaldi, M., Beaugrand, J., Balaguer, P., Ducrot, P.-H., Allais, F., 2017. Syringaresinol: A Renewable and Safer Alternative to Bisphenol A for Epoxy-Amine Resins. ChemSusChem 10, 738-746. https://doi.org/10.1002/cssc.201601595

Jaufurally, A.S., Teixeira, A.R.S., Hollande, L., Allais, F., Ducrot, P.-H., 2016. Optimization of the Laccase-Catalyzed Synthesis of ( \pm )-Syringaresinol and Study of its Thermal and Antiradical Activities. ChemistrySelect 1, 5165-5171. https://doi.org/10.1002/slct.201600543 
Khattab, R., Eskin, M., Aliani, M., Thiyam, U., 2010. Determination of Sinapic Acid Derivatives in Canola Extracts Using High-Performance Liquid Chromatography. Journal of the American Oil Chemists' Society 87, 147-155. https://doi.org/10.1007/s11746-009-1486-0

Khattab, R., Goldberg, E., Lin, L., Thiyam, U., 2010. Quantitative analysis and free-radicalscavenging activity of chlorophyll, phytic acid, and condensed tannins in canola. Food Chemistry 122, 1266-1272. https://doi.org/10.1016/j.foodchem.2010.03.081

Li, J., Guo, Z., 2016. Concurrent extraction and transformation of bioactive phenolic compounds from rapeseed meal using pressurized solvent extraction system. Industrial Crops and Products 94, 152-159. https://doi.org/10.1016/j.indcrop.2016.08.045

Maiga, H.A., Bauer, M.L., Dahlen, C.R., Badaruddin, M., Scholljegerdes, E.J., 2011. Mustard bran in lactating dairy cow diets. Journal of Dairy Science 94, 3054-3062. https://doi.org/10.3168/jds.2010-3971

Marles, M.S., Gruber, M.Y., 2004. Histochemical characterisation of unextractable seed coat pigments and quantification of extractable lignin in the Brassicaceae. J. Sci. Food Agric. 84, 251-262. https://doi.org/10.1002/jsfa.1621

Martínez-Patiño, J.C., Gullón, B., Romero, I., Ruiz, E., Brnčić, M., Žlabur, J.Š., Castro, E., 2019. Optimization of ultrasound-assisted extraction of biomass from olive trees using response surface methodology. Ultrasonics Sonochemistry 51, 487-495. https://doi.org/10.1016/j.ultsonch.2018.05.031

Matthäus, B., Angelini, L.G., 2005. Anti-nutritive constituents in oilseed crops from Italy. Industrial Crops and Products 21, 89-99. ttps://doi.org/10.1016/j.indcrop.2003.12.021

Mayengbam, S., Aachary, A., Thiyam-Holländer, U., 2014. Endogenous Phenolics in Hulls and Cotyledons of Mustard and Canola: A Comparative Study on Its Sinapates and Antioxidant Capacity. Antioxidants 3, 544-558. https://doi.org/10.3390/antiox3030544

Milkowski, C., Strack, D., 2010. Sinapate esters in brassicaceous plants: biochemistry, molecular biology, evolution and metabolic engineering. Planta 232, 19-35. https://doi.org/10.1007/s00425-010-1168-z

Mouterde, L.M.M., Allais, F., 2018. Microwave-Assisted Knoevenagel-Doebner Reaction: An Efficient Method for Naturally Occurring Phenolic Acids Synthesis. Frontiers in Chemistry 6. https://doi.org/10.3389/fchem.2018.00426

Newkirk, R., Classen, H., Tyler, R., 1997. Nutritional evaluation of low glucosinolate mustard meals (Brassica juncea) in broiler diets. Poultry Science 76, 1272-1277. https://doi.org/10.1093/ps/76.9.1272

Nićiforović, N., Abramovič, H., 2014. Sinapic Acid and Its Derivatives: Natural Sources and Bioactivity: Sinapic acid and its derivatives.... Comprehensive Reviews in Food Science and Food Safety 13, 34-51. https://doi.org/10.1111/1541-4337.12041

Peyrot, C., Peru, A.A.M., Mouterde, L.M.M., Allais, F., 2019. Proline-Mediated KnoevenagelDoebner Condensation in Ethanol: A Sustainable Access to $p$-Hydroxycinnamic Acids. ACS Sustainable Chemistry \& Engineering 7, 9422-9427. https://doi.org/10.1021/acssuschemeng.9b00624

Peyrot, C., Mouterde, L.M.M., Mention, M.M., Fournier, R., Allais, F., 2020. Nouvelle voie de synthèse du sinapoyl malate, de la sinapine et de leurs analogues, et leur utilisation en tant que molecules anti-uv. Patent FR2001241

Sarwar, G., Bell, J.M., Sharby, T.F., Jones, J.D., 1981. Nutritional evaluation of meals and meal fractions derived from rape and mustard seed. Can. J. Anim. Sci. 61, 719-733. https://doi.org/10.4141/cjas81-087

Sehwag, S., Das, M., 2015. A brief overview: Present status on utilization of mustard oil and cake. Indian Journal of Traditional Knowledge 14, 244-250.

Singleton, V.L., Orthofer, R., Lamuela-Raventós, R.M., 1999. [14] Analysis of total phenols and other oxidation substrates and antioxidants by means of folin-ciocalteu reagent, in: Methods in Enzymology. Elsevier, pp. 152-178. https://doi.org/10.1016/S0076-6879(99)99017-1

Stalikas, C.D., 2007. Extraction, separation, and detection methods for phenolic acids and flavonoids. Journal of Separation Science 30, 3268-3295. https://doi.org/10.1002/jssc.200700261 
Thiyam, U., Stöckmann, H., Zum Felde, T., Schwarz, K., 2006. Antioxidative effect of the main sinapic acid derivatives from rapeseed and mustard oil by-products. European Journal of Lipid Science and Technology 108, 239-248. https://doi.org/10.1002/ejlt.200500292

Thomas, J., Kuruvilla, K.M., Hrideek, T.K., 2012. Mustard, in: Handbook of Herbs and Spices. Elsevier, pp. 388-398. https://doi.org/10.1533/9780857095671.388

Wang, S.X., Oomah, B.D., McGregor, D.I., 1998. Application and Evaluation of Ion-Exchange UV Spectrophotometric Method for Determination of Sinapine in Brassica Seeds and Meals. Journal of Agricultural and Food Chemistry 46, 575-579. https://doi.org/10.1021/jf9705577 